\title{
RAINFALL VARIABILITY OVER MALAWI DURING THE LATE NINETEENTH CENTURY
}

David J. Nash ${ }^{1,2}$, Kathleen Pribyl ${ }^{1}$, Georgina H. Endfield ${ }^{3}$, Jørgen Klein ${ }^{4}$, George C.D. Adamson ${ }^{5}$

1 Centre for Aquatic Environments, School of Environment and Technology, University of Brighton, Lewes Road, Brighton BN2 4GJ, UK. Email: d.j.nash@brighton.ac.uk; Tel: +44 1273642423

2 School of Geography, Archaeology and Environmental Studies, University of the Witwatersrand, Private Bag 3, Wits 2050, South Africa

3 Department of History, University of Liverpool, 8-14 Abercromby Square, Liverpool L69 7WZ, UK

4 Department of Social Sciences, Inland Norway University of Applied Sciences, PB 400, 2418 Elverum, Norway

5 Department of Geography, King's College London, Strand, London WC2R 2LS, UK

Research sponsor: The Leverhulme Trust Research Project Grant F/00 504/D.

ABSTRACT: Establishing long-term records of rainfall variability is essential for understanding changes in the magnitude and frequency of extreme events. The need is particularly pressing for much of Africa, where the instrumental meteorological record rarely stretches back beyond the early twentieth century. This study extends the rainfall record for present-day Malawi back to the mid-nineteenth century through the analysis of historical documentary materials from British and African archives. Textual evidence within documents is used to construct a semi-quantitative chronology of rainfall variability spanning the period 1858-1900. Widespread and severe droughts are identified during the austral summer rainy seasons of 1861-63, 1877-79, 1885-88 and 1892-94, and two unusually wet periods in 1889-92 and 1894-98. Instrumental rainfall data from Cape Maclear, Bandawe and Kaningina, spanning the period 1876-80 - the earliest so far discovered for Malawi - are compared with nearby long-term records from the Global Historical Climatology Network database. These analyses confirm the classifications for the equivalent years in the semiquantitative chronology. The results of this study are considered alongside other annually-resolved rainfall reconstructions for the southern African summer rainfall zone to assess the spatial extent of late-nineteenth century drought and wetter episodes, and to explore the distribution of teleconnections arising from historical El Niño events. The very strong 1877 El Niño event was associated with drought from northern Malawi to the Eastern Cape. In contrast, drier conditions during the strong 1885 El Niño extended from Malawi as far south as the southern Kalahari, with Lesotho and KwaZulu-Natal experiencing relatively wet conditions. The very strong $1891 \mathrm{EI}$ Niño was associated with very wet conditions from Malawi to KwaZulu-Natal. In contrast, wetter conditions only extended as far south as Zimbabwe following the moderate $1896 \mathrm{EI}$ Niño. The study concludes with suggestions on how to extend historical climate information for the region.

KEYWORDS: Historical climatology; documentary evidence; drought; El Niño; Africa 


\section{Introduction}

Climate change, coupled with high population growth, rapid deforestation, and widespread soil erosion, poses a serious challenge to Malawi's predominantly agriculture- and fisheries-based economy (Allison et al., 2009; Stringer et al., 2009; Jorstad and Webersik, 2016). Of particular concern are potential shifts in the frequency and intensity of extreme events such as intense rainfall, floods, seasonal droughts, and multi-year droughts. Climate modelling work by Adhikari and Nejadhashemi (2016), for example, suggests that by 2050 the north of the country will become more prone to flooding and the south to drought. However, the accuracy of such projections is dependent upon (a) the ability of climate models to simulate the transitional tropical to subtropical climate of the region, and (b) the availability of instrumental data for model validation and with which to provide a baseline against which any long-term changes can be assessed.

The performance of climate models for Malawi has, to date, been mixed. In a comparative analysis by Osborn et al. (2016), for example, all 18 of the QUMP ensemble of models projected a reduction in precipitation across the country of at least 10\% (relative to the 1960-1990 mean) for $2^{\circ} \mathrm{C}$ of warming. In contrast, 10 out of 21 CMIP5 climate models projected an increase in precipitation for the same amount of warming. The availability of instrumental data is better in Malawi in comparison to many countries in Africa (Nicholson et al., 2012a). The country has an extensive network of meteorological stations, with rainfall data having been recorded continuously at Zomba Agricultural College and the Thornwood tea estate (near Mulanje) since 1892, shortly after the country became a British Protectorate. However, records prior to 1900 are limited to the south of the country and, for many stations, are fragmented.

The aim of this study is to extend the rainfall record for Malawi, including the timing and relative severity of extreme events such as droughts and unusually wetter periods, back to the midnineteenth century. This will (a) provide a longer timeframe for climate model evaluation, and (b) permit an exploration of the stability of medium-to-long term influences upon rainfall variability in eastern central Africa, such as the El Niño-Southern Oscillation (ENSO). To achieve this aim, we analyse historical documentary materials from British and African archives to generate the first documentary-derived rainfall reconstruction specifically for the country. We also summarise newly discovered instrumental rainfall data recorded by missionaries at Cape Maclear, Kaningina and Bandawe in the late 1870s and early 1880s, the earliest available for Malawi. Having explored the evidence for major drier and wetter periods during the latter nineteenth century, we compare our results against other annually-resolved records from the southern African summer rainfall zone, including the time-series of fluctuations in lakes Malawi and Chilwa by Nicholson (1998) and the regional rainfall reconstruction by Nicholson et al. (2012b). We conclude with a consideration of the impacts of historic El Niño events upon rainfall distribution and variability. 


\section{Contemporary climatology of Malawi}

Malawi has a mild sub-tropical climate that is strongly seasonal (Jury and Mwafulirwa, 2002). Annual rainfall totals average $1200 \mathrm{~mm}$, with the majority of rainfall concentrated during the austral summer months of December-March (Ngongondo et al., 2011a; Ngongondo et al., 2011b) (Figure 1). The precipitation regime is strongly influenced by topography and the presence of Lake Malawi. Rainfall can be discriminated into four homogenous regions (Figure 1), with differing average annual rainfall totals and contributions from the early and late rains to these totals. These include: (1) a 'Coastal' region along the western shore of Lake Malawi; (2) a 'Northern' region paralleling the western border with Zambia; (3) a 'Central' region including Lilongwe and southernmost Lake Malawi; and (4) a 'Southern' region encompassing the remainder of the country south of Lake Malombe (Nicholson et al., 2014).

The onset of the summer rainy season is relatively uniform across the country (Nicholson et al., 2014), ranging from mid-November to early December. The rainy season normally ends in midMarch to early April, except for stations in region 1 (close to Lake Malawi), where the heaviest rains occur in March-April (Nicholson et al., 2014) and the season may persist until mid- to lateApril or early May (Ngongondo et al., 2011a). Despite contributing only $20-25 \%$ of annual rainfall totals, the late rains in March-April account for $40 \%$ (in regions $2-4$ ) to $66 \%$ (in region 1 ) of interannual rainfall variability (Nicholson et al., 2014).

A recently identified feature of the rainfall distributions shown in Figure 1 is a 'break season' during late February, most evident in regions 1 and 2 (both of which exhibit a double rainfall peak). Nicholson et al. (2014) suggest that this break represents a shift in atmospheric circulation regimes, with a strongly tropical influence on the early rainy season, and an extra-tropical influence on the late rains as the Tropical Easterly Jet moves equatorward. This break is also evident in Botswana somewhat earlier in the season, giving credence to this interpretation.

Interannual rainfall variability over Malawi is influenced by a variety of factors, and the patterns are complex. One of the most common spatial patterns of interannual variability is that when rainfall is above average in the north of the country, it is below average in the south, with a secondary pattern characterised by similar trends across the country (Nicholson, 1998, 2014). On rare occasions, the country is affected by tropical cyclones penetrating the southern African mainland from the southwest Indian Ocean; these may bring drier or wetter conditions according to their track (Jury and Mwafulirwa, 2002; Mavume et al., 2009). Reduced or enhanced rainfall may also occur as a result of teleconnections associated with ENSO. The precise influence of ENSO on rainfall levels can be difficult to predict as the country is located between two regions of opposing climatic response to El Niño. Typically, below-normal precipitation occurs in southeastern parts of 
the southern African summer rainfall zone during the rainy season following an El Niño event, while eastern equatorial Africa may experience enhanced rains (Nicholson and Entekhabi, 1986; Ropelewski and Halpert, 1987; Allan et al., 1996; Nicholson and Kim, 1997). Northern Malawi may, therefore, be wetter than average during an El Niño year and the south drier. However, depending upon the geographical distribution of the ENSO influence, more widespread drier or wetter conditions may arise.

\section{Materials and methods}

Historical documentary materials for this study were analysed in archives in Malawi, South Africa and the UK; the main collections are summarised in Table 1. The earliest documents consulted were written by members of the British-funded Second Zambesi Expedition (1858-1864), led by Dr David Livingstone and representing the first European expedition to reach Lake Malawi (Dritsas, 2010). The materials consulted from this expedition included journals and letters written by the botanist John Kirk, missionary James Stewart, geologist Richard Thornton, and Livingstone himself. Records of the ill-fated 1861 Universities' Mission to Central Africa (UMCA) expedition up the Zambesi into the Shire Highlands (Rowley, 1866), led by Charles Mackenzie, were also scrutinised. However, the most extensive sources consulted were letters, journals, and reports written by missionaries based at Protestant mission stations across the former Central Africa mission field (Figure 2). These included representatives of the UMCA, Free Church of Scotland, and established Church of Scotland, which founded mission stations in 1861 (at Magomero), 1875 (Cape Maclear) and 1876 (Blantyre) respectively. These materials were supplemented by collections of UK Foreign Office correspondence, regional newspapers, commercial papers (including the records of the African Lakes Company Ltd and its successors, which operated freight and transport services on Lake Malawi from 1877 onwards), and other diaries and monographs.

Following standard approaches used in historical climatology (cf. Nicholson, 1979, 1981; Nash and Endfield, 2002; Brázdil et al., 2005; Kelso and Vogel, 2007; Nash and Endfield, 2008; Nash and Grab, 2010; Nash et al., 2016), each of the collections in Table 1 were read in detail, with all information about climatic and related environmental conditions (e.g. descriptions of droughts and floods, river and lake levels, and harvest quantity and quality) recorded verbatim. Quotations were entered and coded within a dedicated database, which allowed information to be sorted (i) chronologically by hydrological 'rain-year' (July-June), and (ii) according to the homogenous rainfall regions determined by Nicholson et al. (2014) (Figure 1). Only those quotes where the climate event could be dated with reasonable accuracy (ideally to a specific month or season) were used. Owing to a lack of historical information for locations close to the Zambia border (cf. Figure 2), rainfall reconstruction was only possible for regions 1, 3 and 4. For these regions, 1751 quotations were collected spanning the period 1858-1900, an average of 20 per year (Figure 3). Early 
instrumental rainfall data for the Free Church of Scotland missions at Cape Maclear (region 3), Bandawe and Kaningina (both region 1), were scanned at the National Library of Scotland (NLS) and later digitised.

Based on the information contained with the collated quotations, seasonal (JAS, OND, JFM, $\mathrm{AMJ}$ ) and annual rainfall series were derived collaboratively for each of the three homogenous rainfall regions by contributors Nash and Endfield. Following Nash et al. (2016), each season was initially grouped into one of five rainfall classes: +2 (very wet/floods), +1 (relatively wet), 0 (normal, seasonal rains), -1 (relatively dry), -2 (very dry/drought). Scores of +2 or -2 were reserved only for seasons where observers described extreme wet or dry conditions, often with significant environmental and/or socio-economic impacts, during a major part of the season. Annual rainfall series for each region were derived by summing and averaging the four seasonal values for that rain-year, with the seasonal scores for OND and JFM weighted double to reflect the contribution of rainfall during these months to annual totals. The resulting scores were rounded to the nearest whole number to generate an annual value on the same five-point +2 to -2 scale. Where averaging produced a value of \pm 0.5 or \pm 1.5 , greatest weight was given to the JFM score to determine the final annual classification.

Finally, following Kelso and Vogel (2007), a confidence rating from 1 (low) to 3 (high) was assigned to the classification for each rain-year to reflect the quality of available information. $A$ confidence rating of 1 was given to rain-years where there was a limited number of sources, and/or the quality of available information was low. A rating of 3 , in contrast, was awarded to rain-years with multiple date- and place-specific references to rainfall conditions, and where the level of detail within most quotations was high.

\section{Results}

Information on rainfall variability is relatively sparse for the first 15 years of the study period (Figure 3 ), and covers only homogenous rainfall region 4 in the extreme south of present-day Malawi. However, the quantity of documentary evidence increases from 1874 onwards, following the establishment of the Scottish missions. The results of the qualitative rainfall reconstruction (Figure 4) are, therefore, considered in two parts (1858-1873 and 1874-1900), with a third results section dedicated to the analysis of early instrumental data.

\subsection{Rainfall variability in southern Malawi, 1858-1873}

The late 1850 s and early 1860 s appear to have been a period of extreme drought in southern Malawi. No direct accounts of rainfall conditions are available for the 1859-60 rainy season. 
However, as part of a study of oral histories of drought in former Nyasaland, Stagman (1951) quotes one interviewee who stated "Long ago, the year the Yaos came into the district (1860), there was a severe drought" (p.68). Wetter than normal conditions occurred during the rainy season of 1860-61. Writing from the confluence of the Shire and Zambesi rivers on 21 May 1861, John Kirk described the latter as being "in full flood, covering most of the islands and sweeping off the young corn and rice" (Kew Gardens Archives, DC 60/158); this suggests heavy rainfall across the catchment.

Drought conditions returned during the rainy seasons of 1861-62 and 1862-63. Writing in early 1863, David Livingstone described the occurrence of repeated droughts, as part of an account of the arrival in southern Malawi of slave hunters from Tete in 1861 and 1862:

"A panic seized the people of a large district about Mount Zomba - they fled to the Shire and leaving all their grain behind them - drought and famine followed, and we now daily see its effects in dead bodies floating down the stream (UMCA B4 (II), Livingstone, D., River Shire, 14 February 1863).

Writing in February 1863, Richard Thornton provided further detail on the timing and impact of the 1862-63 drought:

"In this part rain has been very scant this season and most of the crops are dried up, so that there will probably be a great scarcity of provision... During the last few months the natives have been dying off in hundreds through starvation" (Letter from Richard Thornton to James Stewart, Mission Station, Chivisa's, River Shire, 25 February 1863, quoted in Tabler, 1963).

The occurrence of prolonged drought is corroborated by an unnamed reporter in the Natal Witness newspaper in 1863:

"The general condition of the native population throughout the whole valley of the Shire is represented as deplorable in the extreme. The famine which pressed upon them so severely during the past year, and which thus extended from Agulhas up to near the equator, has swept away whole villages; everywhere dead bodies are found among the grass, and daily seen floating down the river. Provisions, in the shape of even the most ordinary food of the country, are not to be bought at any price... between the ravages of drought, famine, and war, the country is rendered extremely desolate; and those who escape from the war by flight, gradually fall victim to the universally prevailing famine" (Natal Witness, 26 June 1863).

The drought of 1862-63 appears to have been the most severe of the period, and pervaded the cultural memory of both European and indigenous populations for some time, apparently even influencing the choice of site for the first 'Livingstonia Mission' station at Cape Maclear. Writing some 15 years after the drought, the missionary Edward D. Young noted:

“The terrible famine of 1862, which acted so disastrously against the Universities' Mission station in the hills and at Chivisa's, is talked of to this day, and the state of things before and 
since is contrasted, when the natives speak of the wholesale disappearance of goats, fowls, and sheep, which then took place. It is here that the Free Church of Scotland has shown such wisdom in planting its thriving station on the Lake. In that district famine cannot come. Fish is always to be had, whilst the Lake has in numerous places sufficient damp ground, at the deltas of rivers and streams, for instance, to supply a great quantity of rice and corn, be a drought never so severely felt at a distance inland" (Young, 1877 p.188).

Where sufficient information is available to permit reconstruction, rainfall seems to have been normal for the remainder of the period.

\subsection{Rainfall variability across Malawi, 1874-1900}

A further three episodes of multi-year drought (in the rain-years 1877-79, 1885-88 and 1892-94), and two wetter periods (1889-92 and 1894-98), can be identified from documentary evidence during the last quarter of the nineteenth century (Figure 4). These events are now considered chronologically. Drought appears to have affected large areas of homogenous rainfall regions 1, 3 and 4 during 1877-78, with dry but more variable conditions during 1878-79. The 'Livingstonia Mission' Report for 1878, for example, noted:

"Last season [1877-78] was throughout unfavourable for the attainment of good reliable results in agriculture. Its entire course was prolonged and intense drought. The usual seedtime was far advanced before the soil was in any condition to receive the seed. All cereals suffered more or less from the drought, while the more tender completely succumbed to it" (NLS Ms.7876 Robert Laws, Livingstonia [Cape Maclear], 16 December 1878).

Missionary Robert Laws also described Namkamba, one of the Chiefs local to Cape Maclear, making offerings and sacrifices for rain during the early part of 1878 (Livingstone, 1923, p.141), a probable sign of prolonged drought conditions (cf. Klein et al., 2018, in press). Dry conditions continued along the southern and western margin of Lake Malawi during the rainy season of 187879, with John Gunn of the Cape Maclear mission, for example, noting in his journal on 24 December 1878 that "Drought is again making itself felt on our light soils" (NLS Ms.7906/11-20, The Late Mr Gunn's Diary at Livingstonia, published in instalments in the Northern Ensign). Rainfall conditions further south appear to have been normal.

The drought of 1885-88 was felt more widely across Malawi, and was apparently preceded by a truncated rainy season in 1884-85. The Scottish missionary James Sutherland, writing in June 1885 from near Bandawe, noted, "The last rainy season was very short. The rains left us about the middle of March and consequently the crops are not up to an average" (NLS Acc.9220/3, James Sutherland, Sibe Hleli, Angoniland, 17 June 1885). Missionary Walter Elmslie provided detailed accounts of the timing and impact of the 1885-86 drought at Bandawe in his correspondence, summarised in a later monograph: 
"The question of a famine in consequence of drought was agitating the minds of all in the tribe. A few showers fell in the November of the previous year (1885), and the people had planted their maize. It sprang up for a fortnight, and then, as the rains ceased until the 18th of January, the corn was burned up and the people began to be greatly excited. The usual period when rain may be expected is from about the end of November to the end of March, so that towards the middle of January, when the early sowing had been fruitless, and day after day the sun beat down from a cloudless sky and rendered cultivation impossible in the absence of rain, the excitement of the people, with famine staring them in the face, is not to be wondered at" (Elmslie, 1899, p.168).

Below average rainfall was also reported from the northern end of Lake Malawi by the missionary James Bain (NLS MS 7891), with accounts of prayers and rituals for rain noted by missionary George Swinney at Likoma towards the close of the rainy season (UMCA Tin Chest Series G, Rev. G.H. Swinney, Nyasaland Diaries 1884-1897. Vol. 2 - Feb 1886-Oct 1886). The drought appears to have led to severe water shortages in some areas of central Malawi prior to the onset of the 1886-87 rainy season (e.g. NLS Acc.9220/4, Walter Elmslie, Sibehleli, 15 October 1886), which was relatively dry across much of the northern and central parts of the country.

After a good start to the 1887-88 rainy season, severe drought recurred in 1888 following a failure of the rains in February. Walter Elmslie, writing from Njuyu to Robert Laws at Livingstonia on 2 March 1888, noted:

'Rain fell here on three days last month and tho' the maize is looking well the Angoni are in hysterics over the loss of their beer crop... I fear our cabbage is done for, if rain does not come" (NLS MS 7891).

The drought contributed to low levels in the Shire, presenting difficulties for both Scottish mission and African Lakes Company steamboats (Universities' Mission to Central Africa, 1889).

In contrast, the 1890s was a relatively wet decade, with six of the eleven rain-years between 1889 and 1900 classified as having above average precipitation in all three homogenous rainfall regions (see Figure 4). The rains appear to have been particularly heavy during early 1890 and early 1891, with, for example, Walter Elmslie writing from Njuyu in January 1890, "The weather is the worst I have known, wet, foggy, chilly days one after the other" (NLS MS 7893). The situation was echoed by Andrew Murray at Livingstonia who also wrote in January 1890, how "Owing to the continual rains our attendance of children at school is very uncertain" (NLS MS 7893). Heavy rains continued until the first week of April 1890, with Elmslie writing from Bandawe on 31 March:

"We are still in the midst of rain here and it is damp inside as well as outside despite huge fires. I am certainly seeing Bandawe at about its worst and am not disappointed. The rainfall since I came down [from Njuyu, in late February or early March] has been about 27 inches... The natives say, they never saw such weather. Their ranks are being thinned at an alarming rate. The sheep have all died or are all dying" (NLS MS 7893). 
Three years of above-average rainfall were followed by drought in region 4 (in 1892-93) and region 1 (1893-94), with normal rains or wetter conditions elsewhere. This affected navigation on the Shire River, with a newspaper report from July 1894 outlining the situation:

"It is reported from Fort Johnson that the level of Lake Nyasa [Malawi] is lower this year than has been recorded at the same date in previous years. This will probably mean that the Lower Shire will become impassable for steamers, near Chiromo, at an early date: and we may look forward to the next six months as difficult ones for Lower River transport. Although the past rainy season has been an unusually heavy one in the Shire Highlands, the rainfall on the Lake has been lighter than it generally is. The depth of the Lower Shire in the latter half of the year depends on the level of the Lake, and a low Lake means, a low river" (The British Central Africa Gazette Vol. 1 (10), 28 July 1894).

With the exception of the south of Malawi, which experienced extreme drought during the 18991900 rainy season, much of the remainder of the nineteenth century was relatively wet. No abnormally wet episodes can be identified from documentary evidence. However, the journal entry for 1 March 1896 by Edward Alston, an officer of the Coldstream Guards seconded to the British Central Africa Forces in 1894 (Jenkins, 1990), provides an insight into general conditions:

\footnotetext{
"This place [Fort Mangochi] is like one I read of in a book somewhere or other, that it rains every three days out of four, the reason that it does not rain on the fourth day being that every fourth day is set apart for a deluge!" (Society of Malawi Library, Manuscripts, The Diary of Edward Alston, 1894-1896).
}

Four years of above average rainfall had positive benefits for communication between Lake Malawi and the coast, as evidenced in the following newspaper entry:

\begin{abstract}
"Although the extraordinary rainy season has certainly had a bad effect on the health of Europeans, it has brought us back to a far better state of things in regard to the navigability of the river Shire..." (The British Central Africa Gazette Vol 3 (9), 1 May 1896).
\end{abstract}

A comparison of the annual rainfall classifications for region 4 (Figure 4) against a composite of instrumental data for Zomba Agricultural College and Blantyre for 1892 onwards, downloaded from the Global Historical Climate Network (GCHN) database (https://www.ncdc.noaa.gov/dataaccess/land-based-station-data/land-based-datasets/global-historical-climatology-network-ghcn) and averaged (bottom inset of Figure 4), shows good agreement. The drought-classified rain-years of 1893-94 and 1899-1900, and the wetter rain-years of 1896-98, in particular, stand out clearly in the instrumental series as being well below or above (respectively) the average for the decade.

\title{
4.3 Early instrumental data from Cape Maclear, Bandawe and Kaningina
}

The earliest rainfall data for Malawi currently available within the GHCN database are for 11 months of 1886 at Blantyre Town Hall (data for May 1886 are missing), although continuous data 
recording does not begin until January 1896. However, runs of earlier systematically recorded meteorological data were uncovered during this study. These appear to have been collected in response to an edict issued in 1875 by the Foreign Missions Committee of the Free Church of Scotland to the party exploring Lake Malawi for suitable mission sites:

"For some considerable time - perhaps for two or three years - a Daily Journal should be kept, recording all matters of general interest, and specially, records of daily temperature (three observations if possible), atmospheric changes, the setting in of rain, the directions of winds, the kind of daily employment engaged in by the staff, and immediately following on this, a statement on the health of the party... State facts only at first - give inferences after a time when there appear to be sufficient data to explain any illness, as the connection between kind of weather, work and diet, or special exposure..." (NLS Dep.298/139 Livingstonia, 1875. Instructions to Lake Nyassa Mission Party from Foreign Missions Committee of the Free Church).

Daily journals that include meteorological data are available at the National Library of Scotland for three of the earliest Free Church of Scotland mission stations; there may be others in Malawi. The earliest daily (1 January to 22 July 1876; NLS Ms.7907) and monthly (January 1876 to October 1877; NLS Ms.7908) rainfall data are recorded for the first 'Livingstonia Mission' at Cape Maclear. The daily journal includes uncalibrated barometric pressure (recorded by aneroid barometer), temperature and wind direction data measured three times daily at 06:00, 12:00 and 18:00, plus a daily rainfall total. There are no days in the daily journal without data, so it is reasonable to assume that the monthly totals for the year are accurate. These totals can be compared against available twentieth century instrumental data from the closest meteorological station within the GHCN database, Monkey Bay, approximately $15 \mathrm{~km}$ to the southeast (Figure 5a). This indicates that January and February 1876 were wetter than average, while monthly rainfall totals for the remainder of the 1875-76 rain-year were slightly drier than average. After a relatively dry start, the 1876-77 rainy season appears to have been close to average. These data broadly confirm the annual classifications for these rain-years for region 3 (Figure 4).

Longer runs of daily rainfall data (Figure 6) are available for Bandawe from 1 December 1878 to 30 April 1880, and Kaningina from 1 December 1878 to 30 September 1879 (both NLS Ms.7910). For Bandawe, the heaviest daily rainfall was recorded in late February 1879 and during April 1880, while for Kaningina, February and April 1879 were particularly wet. The monthly rainfall totals for each mission can be compared against long-term instrumental data from Mzuzu, of which Kaningina is now a suburb, the closest meteorological station within the GHCN database (Figure 5). Caution is needed, however, as there are several days during 1879 when rainfall data were not recorded at the two mission stations, and either estimated values or blanks are present in the daily journals. Text entries within the journals indicate that these data gaps were due to either illness or the absence of European missionaries from the respective stations. For Bandawe, these days include 6-11 April (no data recorded; due to absence), 8-11 May (estimated 0.40 inches or 10.2 
mm rain; illness) and 16-23 May 1879 (estimated 2.50 inches or $63.5 \mathrm{~mm}$ rain; absence). For Kaningina, no data are recorded for 1-3 February, 30 April, 1 May, and 10 May 1879, though no reasons are indicated. Where estimated values are available in the original journals these have been included in Figure 5.

A comparison of late nineteenth century with twentieth century rainfall data for Bandawe and Kaningina suggests that the portion of the 1878-79 rainy season from December 1878 to February 1879 was slightly wetter than the long-term average at Bandawe (Figure 5b) but much drier than average at Kaningina (Figure 5c). Drier conditions during the early sowing season are likely to have elicited the concerns about drought recorded in historical documents, and influenced the annual rainfall classification for region 1 for 1878-79 shown in Figure 4. This dry period was followed by above average late rains at both stations from February to April 1879. As is the case today, minimal rainfall occurred at both stations between June and November 1879. After a late start of season, rainfall levels at Bandawe during the 1879-80 rainy season were close to the longterm average, with only the late rains in March and April 1880 being above average - this provides independent validation for the 'normal' annual classification for region 1 shown in Figure 4.

\section{Discussion}

\subsection{Comparisons with other regional records}

The only previous study that has considered in detail historical information specifically for Malawi is the reconstruction of water levels in lakes Malawi and Chilwa by Nicholson (1998). Her record identifies that Lake Malawi maintained a relatively high level from the late 1850s until the 1890s, with drops in lake level in some years (Figure 7). The lake began to recede in the mid-1870s, with a dramatic decline occurring sometime after the mid-1880s. In contrast, Lake Chilwa rose rapidly in the 1840 s before falling in the 1860 s, rose again in the mid-1870s before falling in the mid-1880s, and remained relatively dry for the rest of the nineteenth century. Given the size of its catchment, and the nature of interannual rainfall variability across Malawi noted in section 2, interpreting historic fluctuations of Lake Malawi in climatic terms is challenging. Indeed, Nicholson (1998) suggests that lake levels may be reflective of more equatorial than subtropical rainfall. Nonetheless, the impacts of the droughts of the early 1860s, mid-late 1870 s and, in particular, the mid-1880s are visible in the Lake Malawi record. The wetter conditions of the 1890s do not appear to have had a major impact on lake level, with the lake showing only a minor increase. The catchment for Lake Chilwa, in contrast, lies well within the subtropical zone and is more susceptible to local rainfall variability. Again, the impacts of the early 1860 s, mid-late 1870 s and mid-1880s droughts are clearly visible in the lake record. The wetter conditions of the 1890s appear to have had little impact on the lake level, although it should be noted that the 
reconstruction for Lake Chilwa is based on only one data point between 1887 and the early 1900s (see Appendix B in Nicholson, 1998).

The results presented in Figure 4 can also be viewed alongside other annually-resolved records for the southern African summer rainfall zone (Figure 8). These include qualitative rainfall reconstructions derived from documentary evidence (Vogel, 1989; Nash and Endfield, 2002, 2008; Nash and Grab, 2010; Nash et al., 2016) and a semi-quantitative series based on tree ring-widths (Therrell et al., 2006). Regional series for eastern central Africa are also available in Nicholson et al. (2012b).

Considering these records collectively, five major droughts and one protracted wetter period can be identified that affected large areas of the southern African mainland. The spatial extent and severity of the early 1860 s drought has been noted in a number of previous studies (e.g. Kelso and Vogel, 2007, 2015; Nash et al., 2016; Nash, 2017), and appears to have affected regions from the Eastern Cape of South Africa to southern Malawi, and as far west as Namaqualand. The period is also identified as the driest of the nineteenth century in multiproxy rainfall reconstructions by Neukom et al. (2014) and Nash et al. (2016). If the account from the Natal Witness in section 4.1 is accurate, drought conditions may have extended even further north to the Equator. The drought of the late 1870s was most severe in more southerly latitudes of the subcontinent, and does not appear to have been as protracted in Zimbabwe and Malawi. Drought patterns during the 1880s are less spatially coherent, with more southerly areas of southern Africa experiencing drought in the early-mid 1880s, and Malawi in the mid-late 1880s, with Zimbabwe experiencing belowaverage rainfall throughout. Finally, areas as far north as Zimbabwe experienced severe drought in the mid-1890s, while Malawi was relatively wet.

Spatially coherent wetter periods are less common. The only geographically extensive protracted wetter phase apparent from the combined records in Figure 8 was centred on 1890-91. This is also identified as the wettest of the nineteenth century in multiproxy rainfall reconstructions by Neukom et al. (2014) and Nash et al. (2016). Extremely heavy rainfall has been identified previously as occurring in January 1891, affecting areas from former Natal and Zululand (Nash et al., 2016), Lesotho (Nash and Grab, 2010), Botswana and Zimbabwe (Nash and Endfield, 2008); this episode can now be extended into Malawi.

A comparison of the rainfall reconstructions in Figure 4 with the equivalent regions of the Africa-wide rainfall reconstruction produced by Nicholson et al. (2012b) is shown in Figure 9. Extreme events, such as the droughts of the early 1860s, mid- to late-1870s, and mid- to late1880s, and the wetter period centred around 1890-91, are visible in both reconstructions. However, there are discrepancies in other decades. As noted by Hannaford and Nash (2016), with reference 
to conditions in Zimbabwe during the early nineteenth century, the Nicholson et al. (2012b) series appear to overemphasise drier conditions, at least for parts of southern Africa - see, for example, the differences in classification between the late 1870s to mid-1880s or much of the 1890s in Figure 9.

The reasons for the discrepancies in Figure 9 are likely to be methodological. Nicholson et al. (2012b) utilise $a+3$ to -3 scale before averaging to produce a score for each year, whereas this study uses $\mathrm{a}+2$ to -2 scale. However, this is unlikely to account for differences during periods such as the 1890s, where this study identifies a run of wetter years (with scores of +1 and +2 ) but Nicholson et al. (2012b) moderately dry to normal conditions (scores of -1 and 0 ). One explanation may be in the types of documentary and other data used. Similar to the other documentary-based rainfall reconstructions in Figure 8 , this study bases annual rainfall classifications on average conditions described across a large body of mainly unpublished primary documentary materials. Nicholson et al. (2012b) in contrast, utilise smaller numbers of mainly published (and sometimes secondary) documentary materials, combined with gauge data or hydrological sources; an overemphasis of references to dry conditions in these documents could therefore skew the results, particularly for years when only limited gauge data were available.

A greater limitation of the Nicholson et al. (2012b) series for the area covered by present-day Malawi is likely to be the use of statistical inference or spatial reconstruction from neighbouring regions to fill in for years with insufficient data availability. Only those years in the Nicholson series outlined with a heavy black line in Figure 9 were reconstructed directly from proxy data; the remainder are interpolated using data from neighbouring regions. Although the exact replacement regions for each year are not specified, it seems likely for the period 1890-98 that regions 43 and 54 were reconstructed primarily from region 56, located to the southwest of Malawi. One reason for the poor agreement between the studies may be that the southwest-northeast rainfall correlation did not hold during the 1890s. This is borne out through comparison with the semi-quantitative Therrell et al. (2006) tree-ring series for Zimbabwe in Figure 8. This shows drought during the early 1890s; a period of particularly poor agreement between the Zimbabwe series and this study.

\subsection{ENSO and rainfall variability in Malawi during the late nineteenth century}

While noting that Malawi is a node in the regional rainfall response to ENSO (see section 2), the results in Figure 4 can be used to provide a check on the long-term stability of the ENSO-rainfall relationship in east central Africa. Of the 13 El Niño events classified as of moderate strength or above (Gergis and Fowler, 2009) during the study period, four are followed by dry conditions in the succeeding rain-year in at least one of the three homogenous rainfall regions of Malawi, four with wetter conditions, and two with normal rainfall. Three more El Niño years fall during the period 
1864-1874 when it was not possible to produce reliable rainfall classifications owing to a lack of documentary evidence. Droughts and very wet periods also occur during a number of 'non-El Niño' years.

Figure 8 also provides insights into the spatial extent of teleconnections arising from individual historical El Niño events. The very strong El Niño event of 1877 was associated with drought from the Eastern Cape to northern Malawi during the rainy season following the event. This suggests an expansion of the drier conditions often associated with EI Niño beyond the southeast of the southern African subcontinent. In contrast, drier conditions associated with the strong El Niño event of 1885 extended from Malawi as far south as the southern Kalahari, with Lesotho and KwaZulu-Natal experiencing relatively wet conditions. The very strong El Niño event of 1891 coincided with very wet conditions throughout Malawi and south to KwaZulu-Natal, possibly suggesting an expansion of the enhanced rains associated with El Niño events in eastern equatorial Africa. In contrast, wetter conditions only extended as far south as Zimbabwe following the moderate 1896 El Niño event, suggesting a limited expansion of the zone of equatorial rainfall.

\section{Conclusions}

The aim of this investigation was to extend the rainfall record for Malawi back to the mid-nineteenth century using historical documentary materials. The key conclusions of the study are as follows:

- Analysis of textual evidence within historical documents indicates that severe droughts affected large areas of the country during the austral summer rainy seasons of 1861-63, 1877$79,1885-88$ and 1892-94, with two unusually wet periods identified in 1889-92 and 1894-98. Many of these major wet and dry periods coincide with ones previously identified by Nicholson et al. (2012b). However, there are discrepancies, particularly for the 1890s, which are likely to be due to either methodological issues or differences in the data used in the respective reconstructions;

- By combining the results of this study with other annually-resolved rainfall reconstructions, droughts and wetter periods of varying spatial extent can be identified across Anglophone southern Africa. Severe drought in the early 1860s affected regions from southern Malawi to the Eastern Cape, and as far west as Namaqualand. The late 1870s drought was most severe in more southerly latitudes of the subcontinent, and was not as protracted in Zimbabwe and Malawi. Drought patterns during the 1880s are less spatially coherent, although Zimbabwe appears to have experienced below-average rainfall throughout the decade. Severe drought affected areas as far north as Zimbabwe during the mid-1890s, although Malawi was relatively wet; 
- The combined rainfall series can also be used to explore the spatial extent of rainfall variability during historical El Niño events. The very strong 1877 El Niño event was associated with drought from northern Malawi to the Eastern Cape during the rainy season following the event, while the strong 1885 El Niño was associated with drier conditions from Malawi to only as far south as the southern Kalahari (with Lesotho and KwaZulu-Natal experiencing relatively wet conditions). In contrast, the very strong $1891 \mathrm{EI}$ Niño was associated with very wet conditions from Malawi to KwaZulu-Natal. Wetter conditions only extended as far south as Zimbabwe following the moderate 1896 El Niño event;

- Newly discovered instrumental rainfall data from Cape Maclear, Bandawe and Kaningina, spanning January 1876 to April 1880 - the earliest continuously recorded meteorological data for Malawi - indicate that rainfall fluctuated around the long-term average during much of this period. Unfortunately, insufficient instrumental data are available to assess the severity of the 1877-78 drought year.

The study demonstrates the effectiveness of historical documents as a source of information about past rainfall variability. Despite concerns over the subjectivity of individual observers, it is possible, given sufficient independent records, to construct robust time-series of climatic conditions. This investigation relied mainly on English-language materials. However, as Nash and Adamson (2014) and Hannaford and Nash (2016) note, extensive collections of colonial records exist for adjacent former Portuguese-speaking areas of southern Africa, and German-speaking areas of eastern Africa, through which rainfall variability for earlier time periods and a broader geographical area could be reconstructed. This would allow for eastern central Africa to make a greater contribution to global efforts at historic atmospheric circulation reconstruction (cf. Allan et al., 2016).

\section{Acknowledgements}

This research was funded by The Leverhulme Trust Research Project Grant F/00 504/D. We extend our thanks to the archivists at the repositories listed in Table 1 for access to collections, including those at the National Library of Scotland who provided scans of early instrumental data; these data were digitised by Liam Hardy. Thanks also to Stan Stanier for designing the ENSOAfrica database used for the storage of documentary evidence. The authors declare no conflict of interest for this study. 


\section{References}

Adhikari U, Nejadhashemi AP. 2016. Impacts of climate change on water resources in Malawi. Journal of Hydrologic Engineering 21: DOI:10.1061/(ASCE)HE.1943-5584.0001436.

Allan R, Lindsay J, Parker D. 1996. El Niño, Southern Oscillation, and Climate Variability. CSIRO: Collingwood.

Allan R, Endfield G, Damodaran V, Adamson G, Hannaford M, Carroll F, Macdonald N, Groom N, Jones J, Williamson F, Hendy E, Holper P, Arroyo-Mora JP, Hughes L, Bickers R, Bliuc AM. 2016. Toward integrated historical climate research: the example of Atmospheric Circulation Reconstructions over the Earth. Wiley Interdisciplinary Reviews-Climate Change 7: 164-174.

Allison EH, Perry AL, Badjeck MC, Adger WN, Brown K, Conway D, Halls AS, Pilling GM, Reynolds JD, Andrew NL, Dulvy NK. 2009. Vulnerability of national economies to the impacts of climate change on fisheries. Fish and Fisheries 10: 173-196.

Beach HP, Fahs CH. 1925. World Missionary Atlas. Institute of Social and Religious Research: New York.

Brázdil R, Pfister C, Wanner H, von Storch H, Luterbacher J. 2005. Historical climatology in Europe - the state of the art. Climatic Change 70: 363-430.

Dritsas L. 2010. Zambesi: David Livingstone and Expeditionary Science in Africa. I.B. Tauris: London.

Elmslie WA. 1899. Among the wild Ngoni; being some chapters in the history of the Livingstonia Mission in British Central Africa. Anderson \& Ferrier: Edinburgh.

Gergis JL, Fowler AM. 2009. A history of ENSO events since A.D. 1525: implications for future climate change. Climatic Change 92: 343-387.

Hannaford MJ, Nash DJ. 2016. Climate, history, society over the last millennium in southeast Africa. Wiley Interdisciplinary Reviews-Climate Change 7: 370-392.

Jenkins P. 1990. Extracts from the diary of Edward Alston, 1894-1896. The Society of Malawi Journal 43: 19-34.

Jorstad H, Webersik C. 2016. Vulnerability to climate change and adaptation strategies of local communities in Malawi: experiences of women fish-processing groups in the Lake Chilwa Basin. Earth System Dynamics 7: 977-989.

Jury MR, Mwafulirwa ND. 2002. Climate variability in Malawi, Part 1: Dry summers, statistical associations and predictability. International Journal of Climatology 22: 1289-1302.

Kelso C, Vogel CH. 2007. The climate of Namaqualand in the nineteenth century. Climatic Change 83: $257-380$.

Kelso C, Vogel CH. 2015. Diversity to decline-livelihood adaptations of the Namaqua Khoikhoi (1800-1900). Global Environmental Change 35: 254-268.

Klein J, Nash DJ, Pribyl K, Endfield GH, Hannaford M. 2018, in press. Climate, conflict and society: changing responses to weather extremes in nineteenth century Zululand. Environment and History.

Mavume AF, Rydberg L, Rouault M, Lutjeharms JRE. 2009. Climatology and landfall of tropical cyclones in the south-west Indian Ocean. Western Indian Ocean Journal of Marine Science 8: 1535. 
Nash DJ. 2017. Changes in precipitation over southern Africa during recent centuries. Oxford Research Encyclopedia of Climate Science: DOI:10.1093/acrefore/9780190228620.013.539.

Nash DJ, Endfield GH. 2002. A 19th century climate chronology for the Kalahari region of central southern Africa derived from missionary correspondence. International Journal of Climatology 22: 821-841.

Nash DJ, Endfield GH. 2008. 'Splendid rains have fallen': links between El Nino and rainfall variability in the Kalahari, 1840-1900. Climatic Change 86: 257-290.

Nash DJ, Grab SW. 2010. "A sky of brass and burning winds": documentary evidence of rainfall variability in the Kingdom of Lesotho, Southern Africa, 1824-1900. Climatic Change 101: 617-653.

Nash DJ, Adamson GCD. 2014. Recent advances in the historical climatology of the tropics and subtropics. Bulletin of the American Meteorological Society 95: 131-146.

Nash DJ, Pribyl K, Klein J, Neukom R, Endfield GH, Adamson GCD, Kniveton DR. 2016. Seasonal rainfall variability in southeast Africa during the nineteenth century reconstructed from documentary sources. Climatic Change 134: 605-619.

Neukom R, Nash DJ, Endfield GH, Grab SW, Grove CA, Kelso C, Vogel CH, Zinke J. 2014. Multiproxy summer and winter precipitation reconstruction for southern Africa over the last 200 years. Climate Dynamics 42: 2713-2716.

Ngongondo CS, Xu CY, Gottschalk L, Alemaw B. 2011a. Evaluation of spatial and temporal characteristics of rainfall in Malawi: a case of data-scarce region. Theoretical and Applied Climatology 106: 79-93.

Ngongondo CS, Xu CY, Tallaksen LM, Alemaw B, Chirwa T. 2011b. Regional frequency analysis of rainfall extremes in Southern Malawi using the index rainfall and L-moments approaches.

Stochastic Environmental Research and Risk Assessment 25: 939-955.

Nicholson SE. 1979. The methodology of historical climate reconstruction and its application to Africa. Journal of African History 20: 31-49.

Nicholson SE. 1981. The Historical Climatology of Africa. In Wigley TML, Ingram MJ, Farmer G. (eds.) Climate and History. Cambridge University Press: Cambridge, pp. 249-270.

Nicholson SE. 1998. Fluctuations of Rift Valley lakes Malawi and Chilwa during historical times: A synthesis of geological, archaeological and historical information. In Lehman JT. (ed.)

Environmental Change and Response in East African Lakes. Monographiae Biologicae, vol 79. Springer: Dordrecht, pp. 207-231.

Nicholson SE. 2014. Spatial teleconnections in African rainfall: A comparison of 19th and 20th century patterns. Holocene 24: 1840-1848.

Nicholson SE, Entekhabi D. 1986. The quasi-periodic behavior of rainfall variability in Africa and its relationship to the Southern Oscillation. Archives for Meteorology Geophysics and Bioclimatology Series a-Meteorology and Atmospheric Physics 34: 311-348.

Nicholson SE, Kim E. 1997. The relationship of the El Nino Southern Oscillation to African rainfall. International Journal of Climatology 17: 117-135.

Nicholson SE, Dezfuli AK, Klotter D. 2012a. A two-century precipitation dataset for the continent of Africa. Bulletin of the American Meteorological Society 93: 1219-1231. 
Nicholson SE, Klotter D, Dezfuli AK. 2012b. Spatial reconstruction of semi-quantitative precipitation fields over Africa during the nineteenth century from documentary evidence and gauge data. Quaternary Research 78: 13-23.

Nicholson SE, Klotter D, Chavula G. 2014. A detailed rainfall climatology for Malawi, southern Africa. International Journal of Climatology 34: 315-325.

Osborn TJ, Wallace CJ, Harris IC, Melvin TM. 2016. Pattern scaling using ClimGen: monthlyresolution future climate scenarios including changes in the variability of precipitation. Climatic Change 134: 353-369.

Ropelewski CF, Halpert MS. 1987. Global and regional scale precipitation patterns associated with the El-Nino Southern Oscillation. Monthly Weather Review 115: 1606-1626.

Rowley H. 1866. The story of the Universities' Mission to Central Africa: From its commencement, under Bishop Mackenzie, to its withdrawal from Zambesi. Saunders, Otley and Co.: London.

Stagman JJ. 1951. Nyasaland droughts. The Nyasaland Journal 4: 67-69.

Stringer LC, Dyer JC, Reed MS, Dougill AJ, Twyman C, Mkwambisi D. 2009. Adaptations to climate change, drought and desertification: local insights to enhance policy in southern Africa. Environmental Science and Policy 12: 748-765.

Tabler EC (ed.) 1963. The Zambezi Papers of Richard Thornton, Geologist to Livingstone's Zambezi Expedition, Vol. 2, Chatto \& Windu, London.

Therrell MD, Stahle DW, Ries LP, Shugart HH. 2006. Tree-ring reconstructed rainfall variability in Zimbabwe. Climate Dynamics 26: 677-685.

Universities' Mission to Central Africa. 1889. Central African Mission Report for 1888-89. UMCA: London.

Vogel CH. 1989. A documentary-derived climatic chronology for South Africa, 1820-1900. Climatic Change 14: 291-307.

Young ED. 1877. Nyasa: a Journal of Adventures Whilst Exploring Nyasa, Central Africa, and Establishing the Settlement of Livingstonia. Murray: London. 

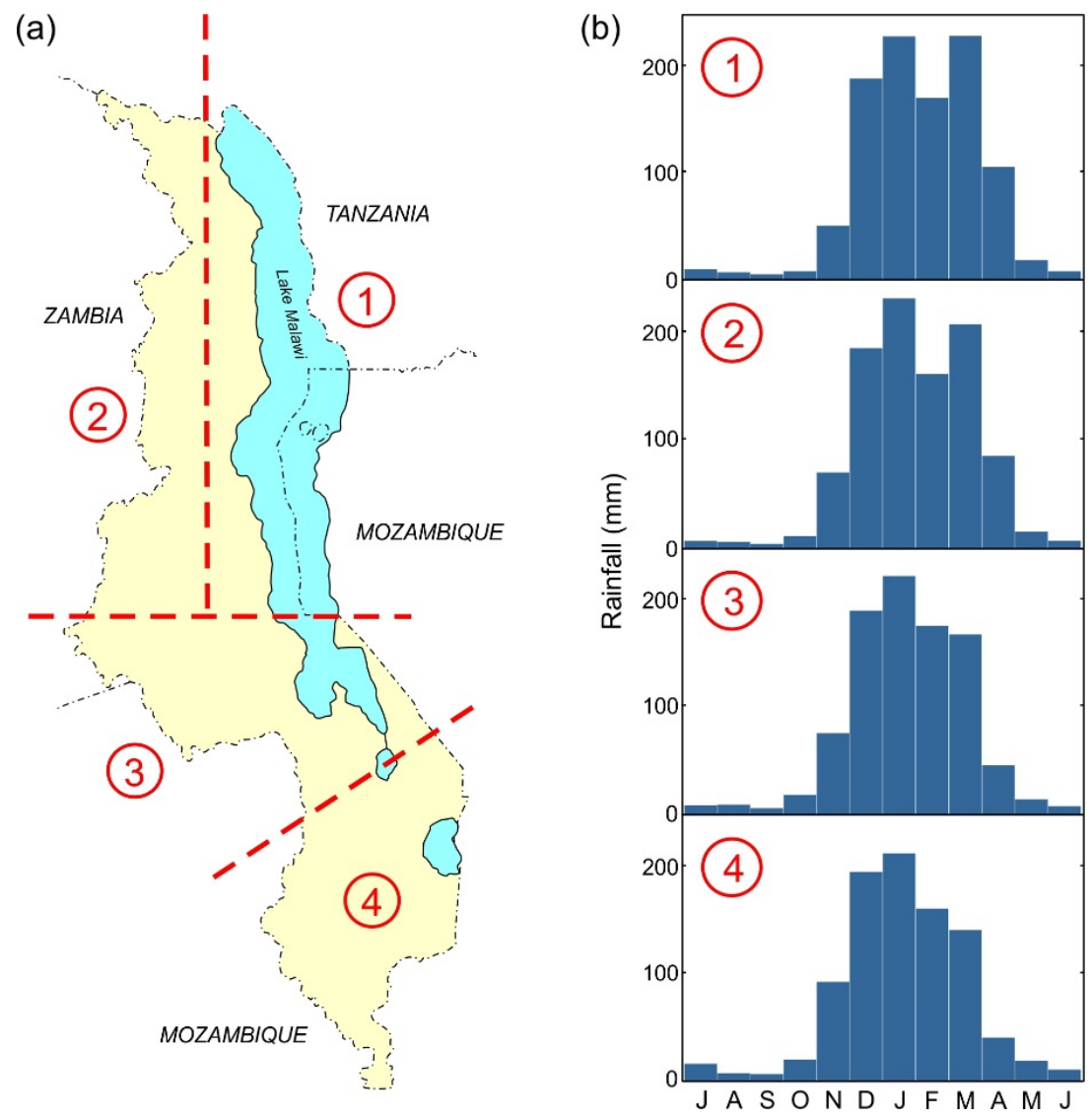

Figure 1: (a) The four homogenous rainfall zones within Malawi, and (b) their associated mean monthly rainfall distribution (derived from twentieth century gauge data; after Nicholson et al., 2014). 


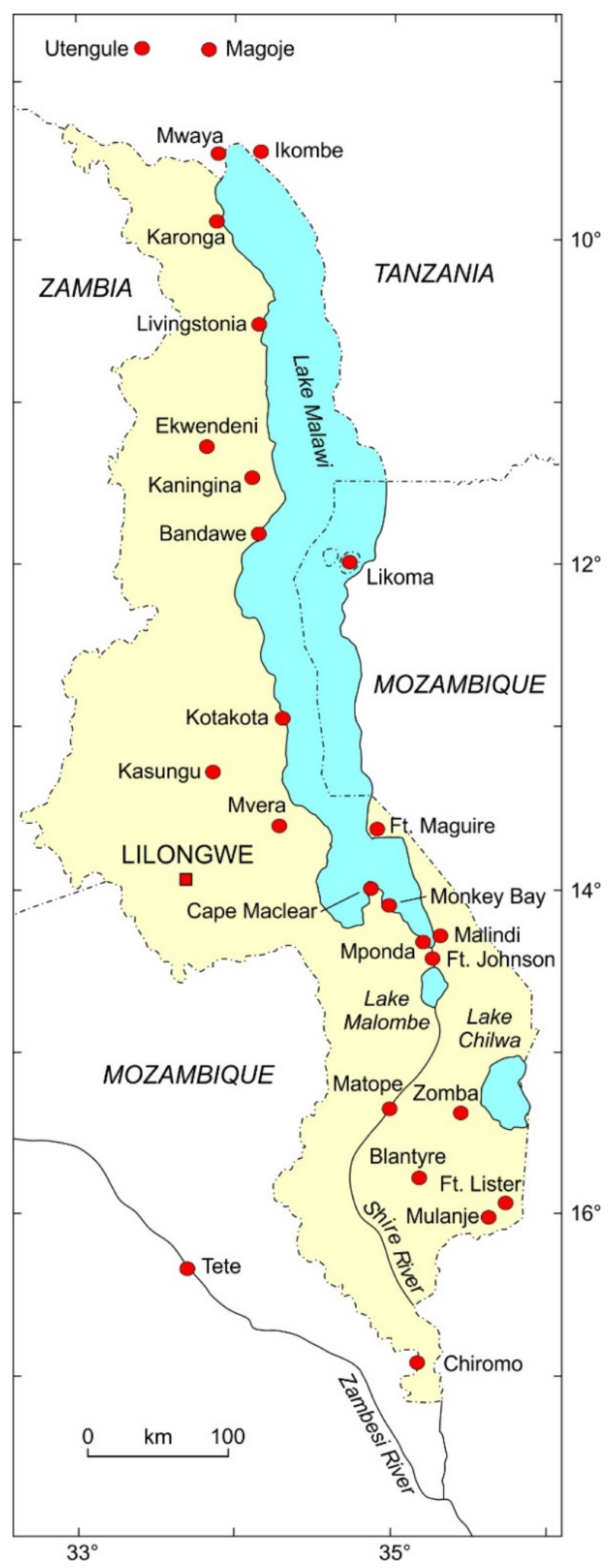

Figure 2: Main locations with documentary evidence of historical rainfall variability. Historical mission station localities mapped from Beach and Fahs (1925). 


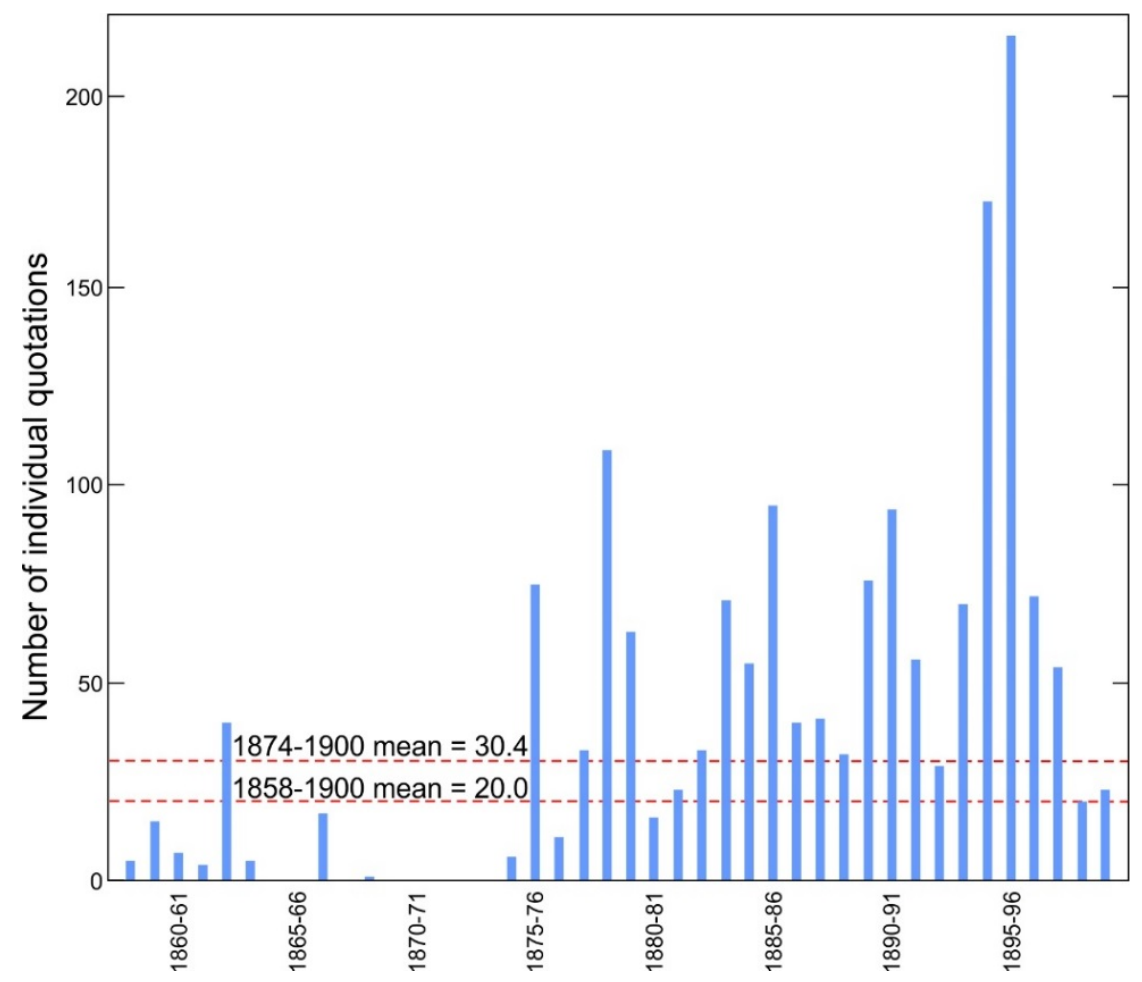

Figure 3: Numbers of individual climate-related quotations per year across the study area. 

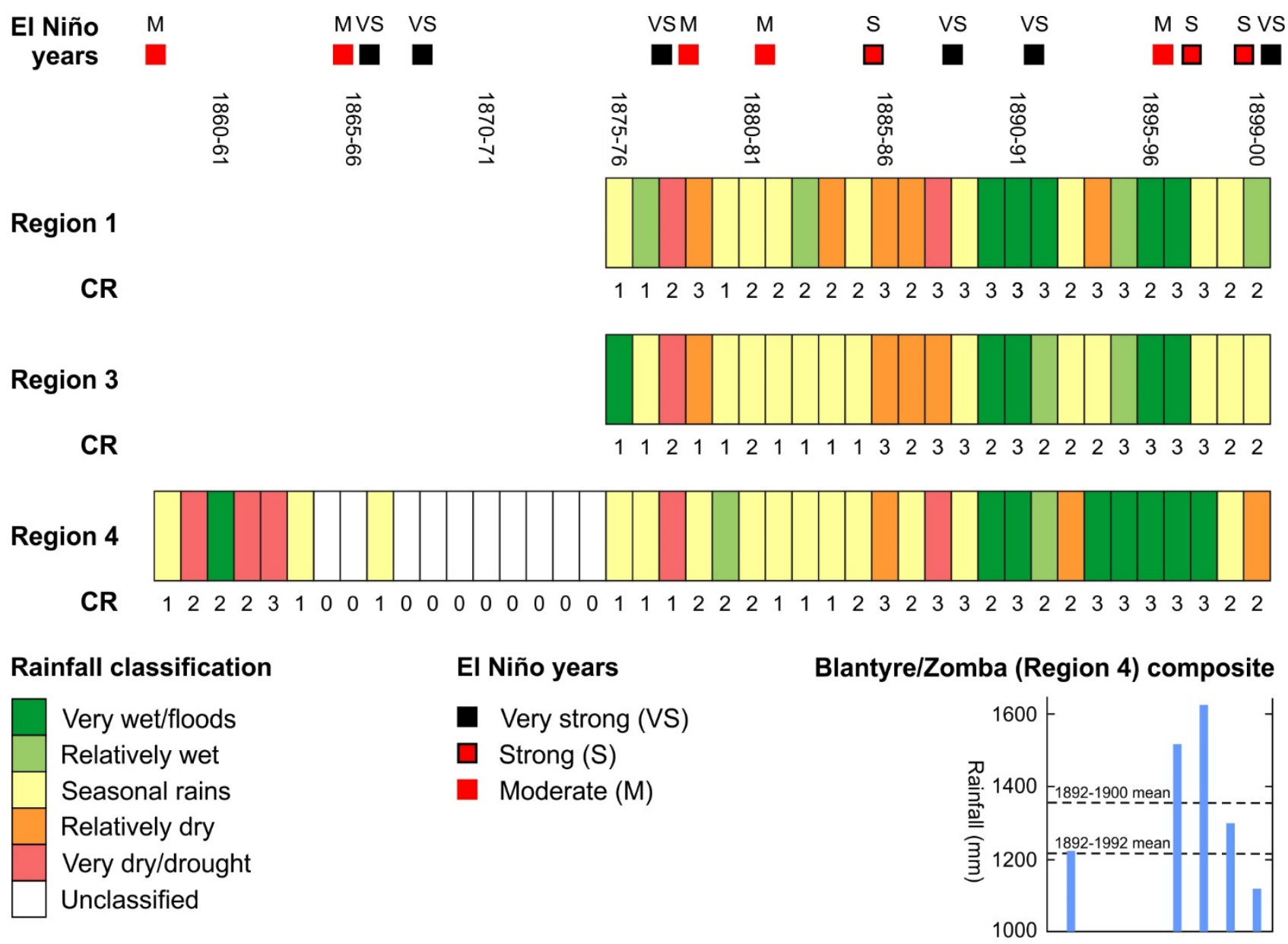

Figure 4: Annual rainfall reconstruction for homogenous rainfall regions 1, 3 and 4 of Malawi (see Figure 1 for locations of regions). CR indicates confidence rating from highest (3) to lowest (1); a value of 0 indicates insufficient evidence to generate a classification. The inset shows average rainfall for Blantyre and Zomba Agricultural College downloaded from the GHCN database; note that data are not available for these stations for 1893-95. El Niño years indicated after Gergis and Fowler (2009). 
(a)

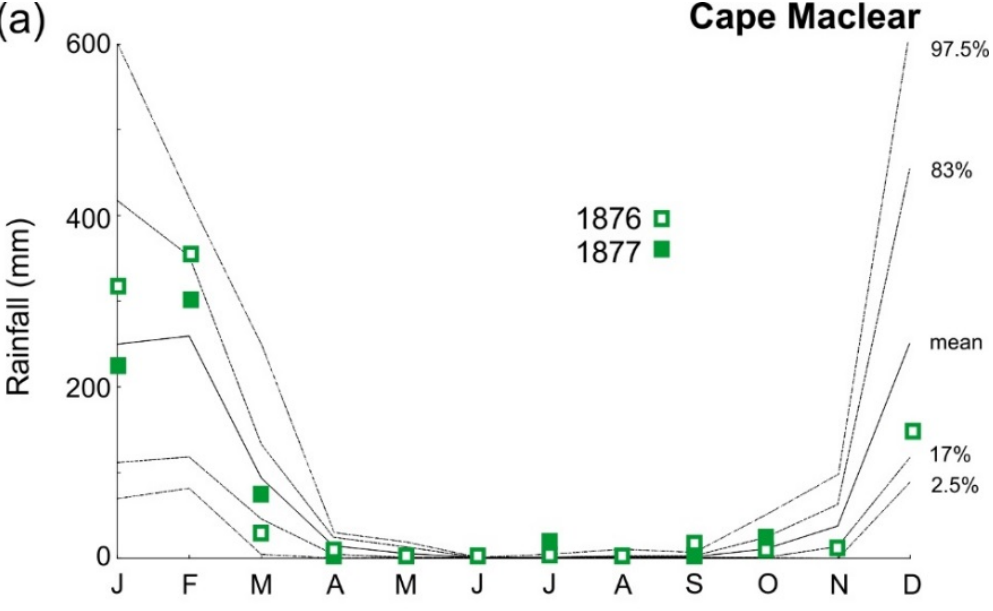

(b)
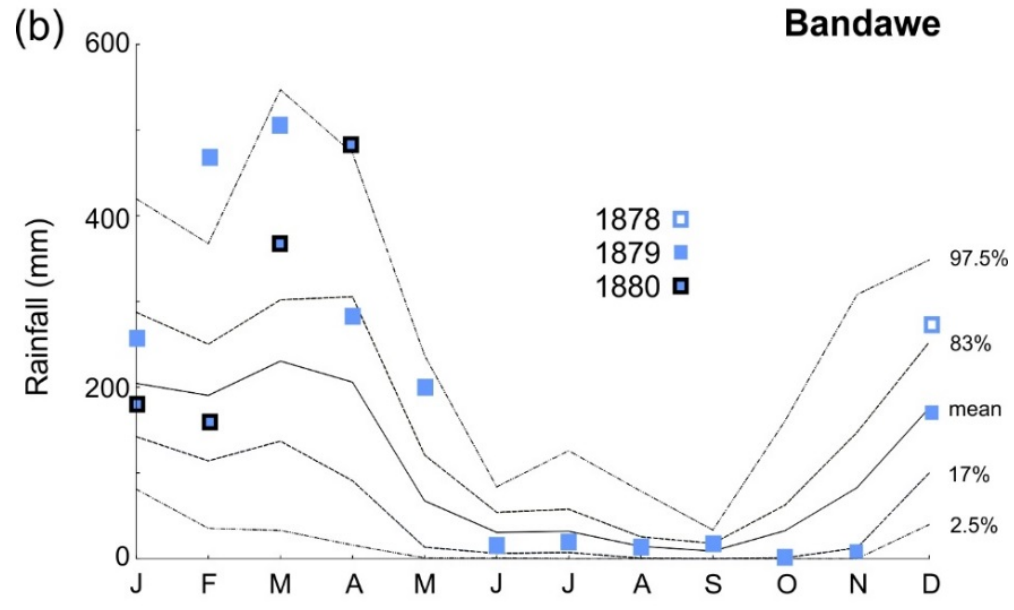

(c) 600

Kaningina

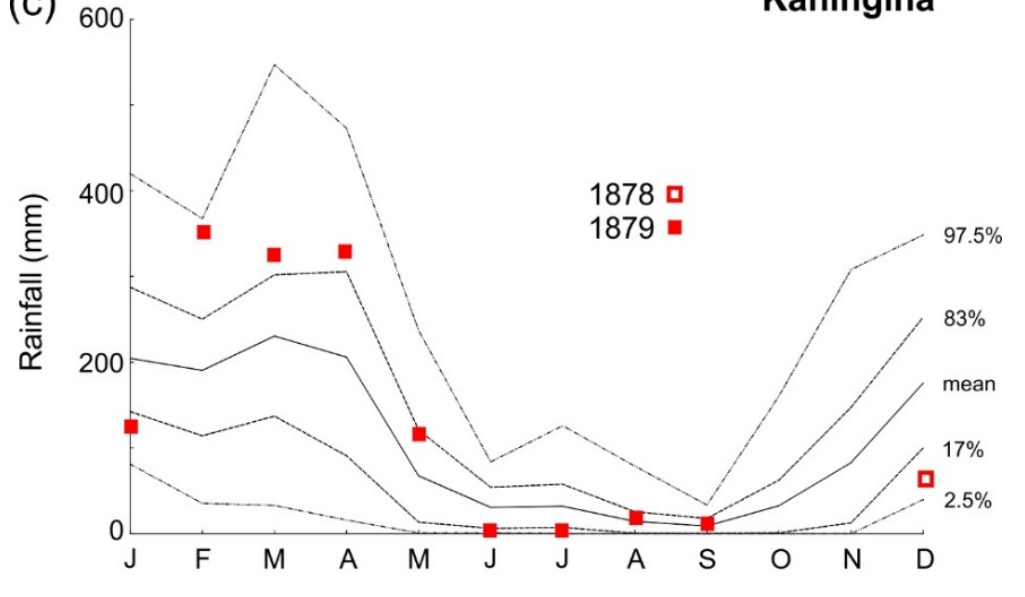

Figure 5: Comparison of monthly rainfall totals for (a) Cape Maclear (January 1876 to October 1877; NLS Ms.7908), (b) Bandawe (December 1878 to April 1880; NLS Ms.7910) and (c) Kaningina (December 1878 to September 1879; NLS Ms.7910) against long-term monthly rainfall data from the GHCN database. Data for Cape Maclear are compared against the mean and 97.5, 83, 17 and 2.5 percentiles of monthly rainfall data for 1980-1990 from Monkey Bay (WMO station code: 67690); values for Bandawe and Kaningina are compared against equivalent monthly data for 1946-2000 from Mzuzu (WMO station code 67489). 


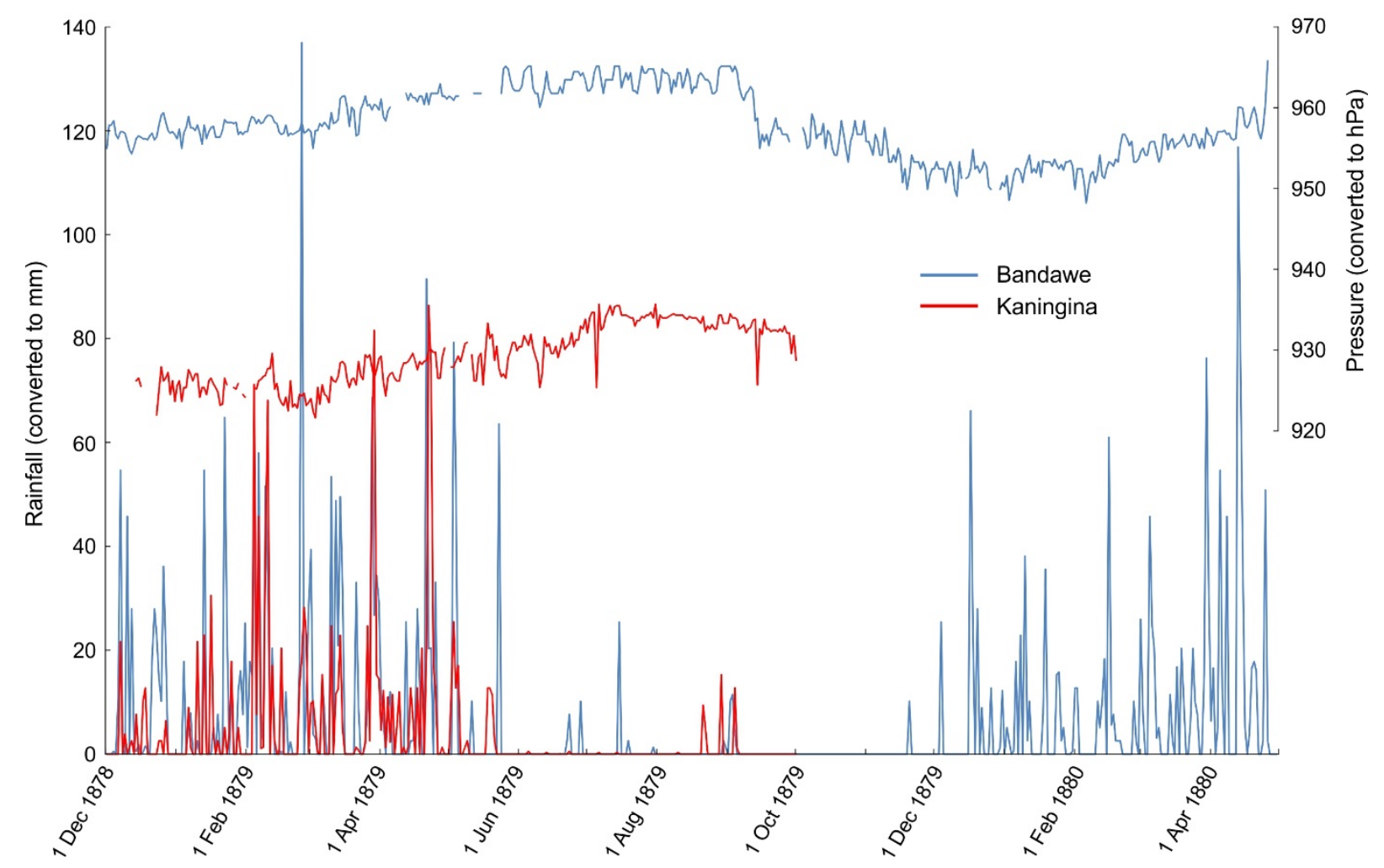

Figure 6: Early instrumental rainfall and uncalibrated barometric pressure data for Bandawe (1 December 1878 to 30 April 1880) and Kaningina (1 December 1878 to 30 September 1879), transcribed from NLS Ms.7910. 


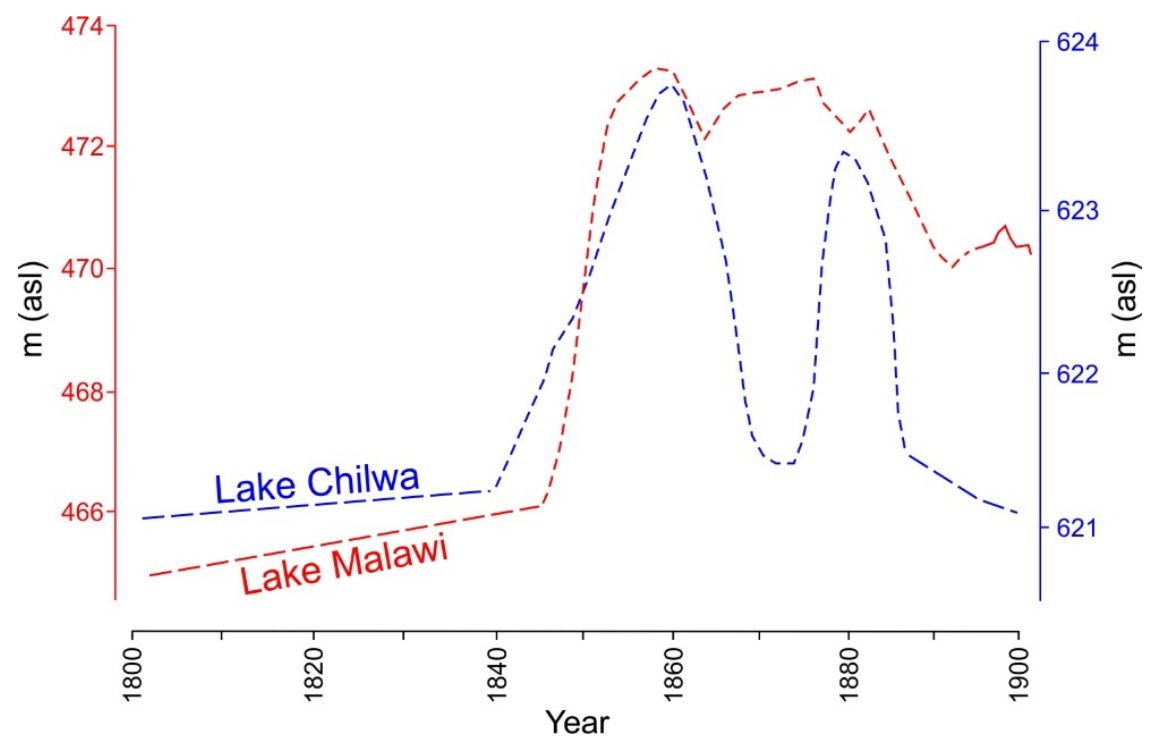

Figure 7: Fluctuations in the level of Lake Malawi (red) and Lake Chilwa (blue) during the nineteenth century (after Nicholson, 1998). Long dashed lines indicate periods of low lake level; short dashed lines indicate trends based on proxy historical data; solid line for Lake Malawi (1896 onwards) indicates the instrumental lake level. 


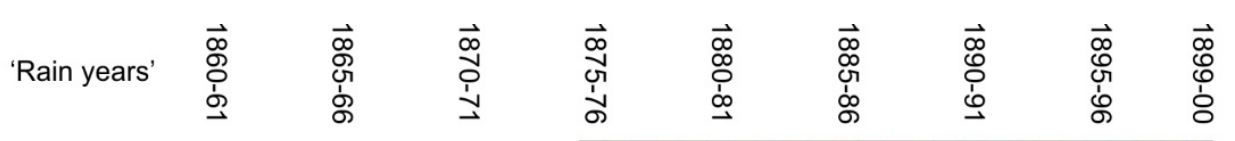

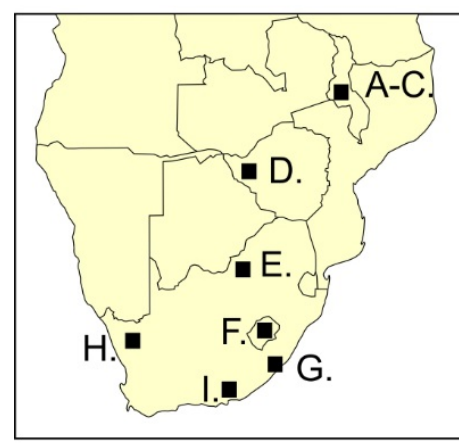

(A) Malawi Region 1

(B) Malawi Region 3

(C) Malawi Region 4

(D) Zimbabwe

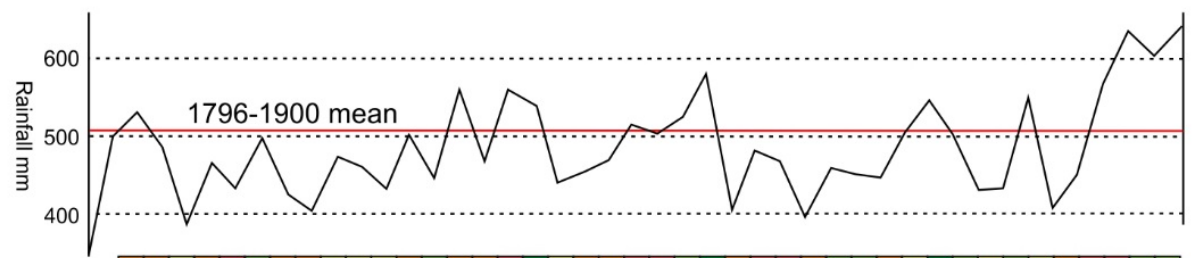

\section{Rainfall classification}

Very wet/floods

Relatively wet

Seasonal rains

Relatively dry

Very dry/drought

Unclassified
(E) Southern

Kalahari

(F) Lesotho

(G) KwaZulu-Natal

(H) Namaqualand
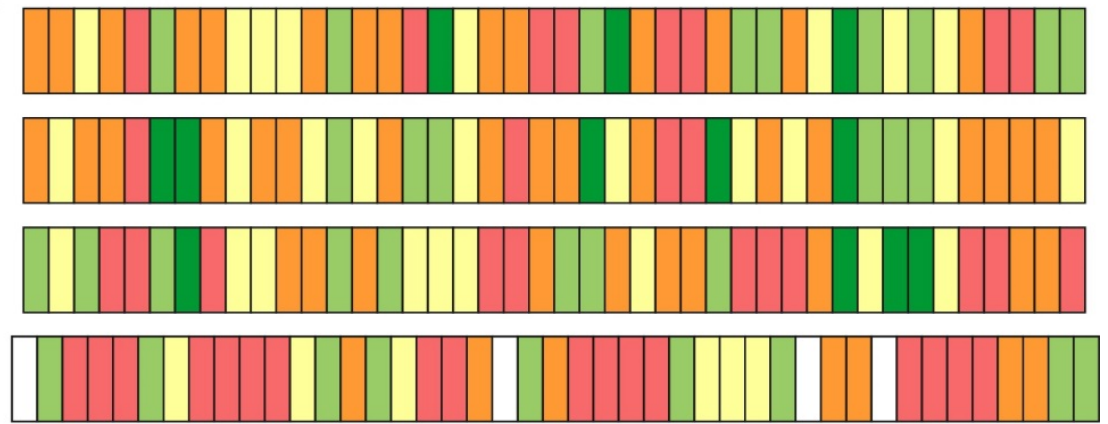

(I) Eastern Cape

Figure 8: Comparison of the results of this study $(A-C)$ with selected annually-resolved series of mid-late nineteenth century rainfall variability for the southern African summer rainfall zone. (D) Tree ring-width series for Zimbabwe (Therrell et al., 2006). (E-I) Documentary-derived series for the southern Kalahari (Nash and Endfield, 2002, 2008), Lesotho (Nash and Grab, 2010), KwaZulu-Natal (Nash et al., 2016), Namaqualand (Kelso and Vogel, 2007), and Eastern Cape (Vogel, 1989). 


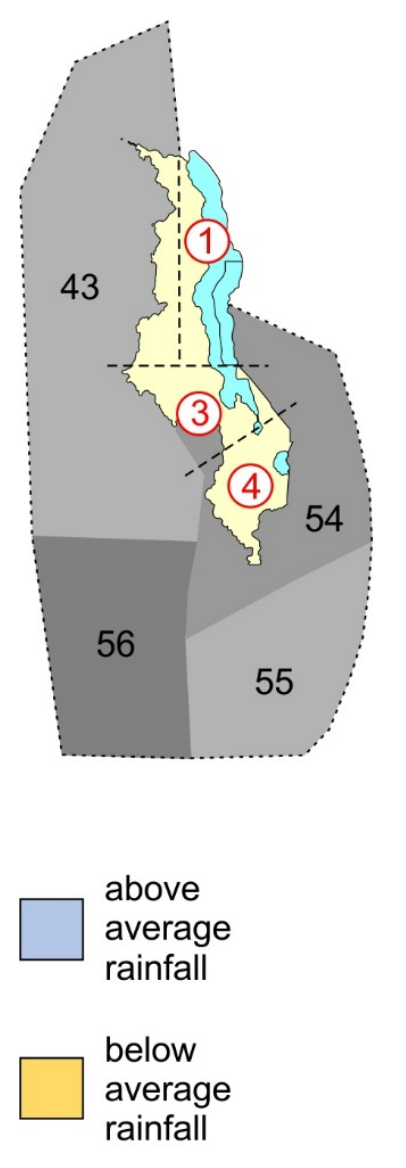

Malawi

Region 1

Malawi

Region 3

Malawi

Region 4

Africa

Region 43

Africa

Region 54

Africa

Region 55

Africa

Region 56

rainfall

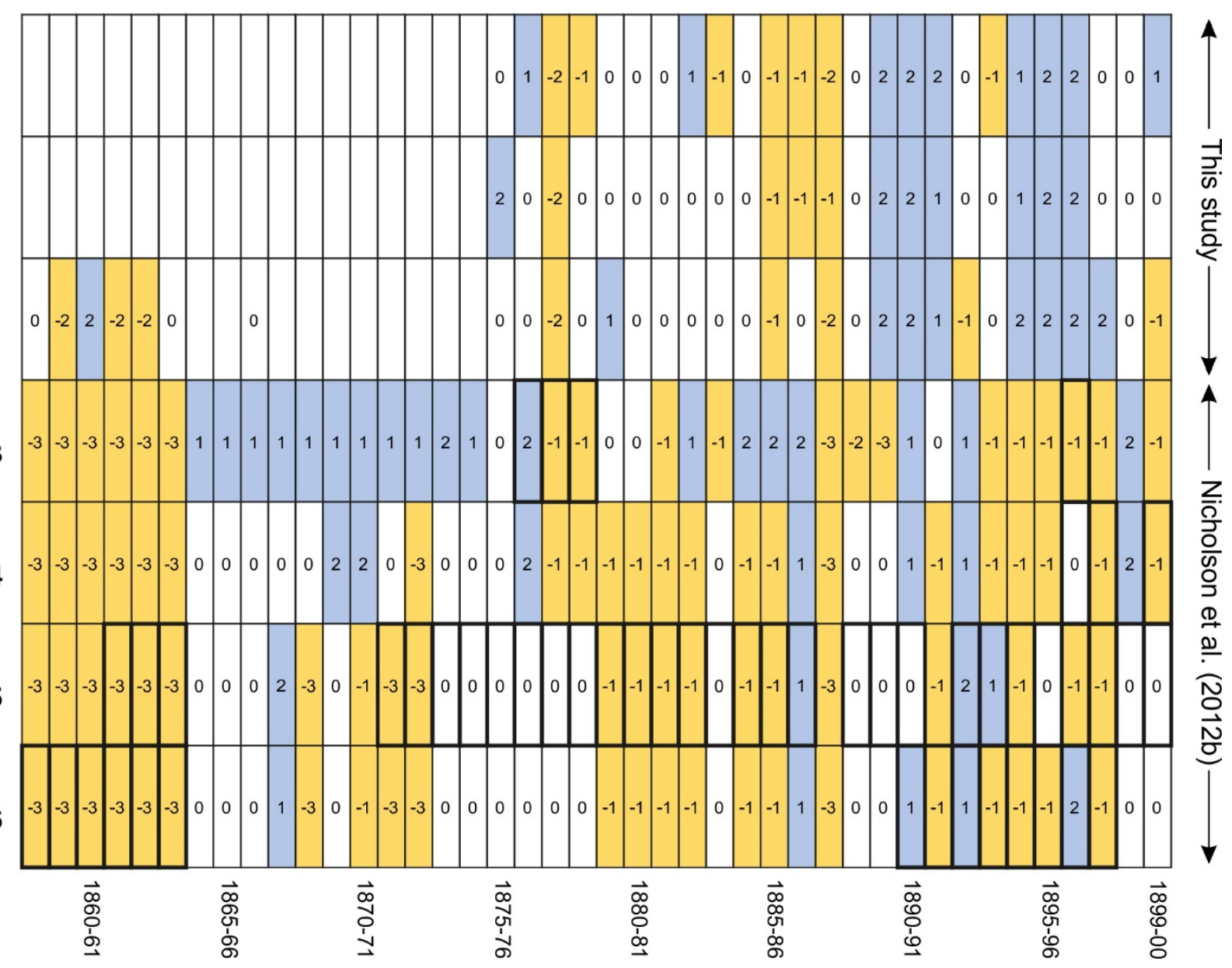

Figure 9: Comparison of the results of this study (regions 1, 3 and 4 - red, circled) against those for regions 43, 54, 55 and 56 in the Africa-wide rainfall reconstruction produced by Nicholson et al. (2012b). Note that the latter reconstruction uses seven rainfall classes (+3 to -3$)$ as opposed to the five (+2 to -2) in this study. Years in the Africa-wide reconstruction classified on the basis of rain gauge, documentary evidence and/or hydrological data are outlined with a heavy black line; classification for other years is based on either statistical inference or spatial reconstruction (see Nicholson et al., 2012b, for an explanation). 
Table 1: Details of main archival collections consulted for this study.

\begin{tabular}{|l|l|}
\hline Name of repository & Key collections consulted \\
\hline $\begin{array}{l}\text { National Archives of Malawi, Zomba, } \\
\text { Malawi }\end{array}$ & $\begin{array}{l}\text { Manuscript collection (including Livingstonia } \\
\text { Mission collection, Foreign Office } \\
\text { correspondence); Occasional Paper for } \\
\text { Nyasaland; Nyasa News }\end{array}$ \\
\hline $\begin{array}{l}\text { Society of Malawi Library, Blantyre, } \\
\text { Malawi }\end{array}$ & $\begin{array}{l}\text { Manuscript collection (including Diary of Edward } \\
\text { Alston, 1894-96); Nyasaland Journal; The British } \\
\text { Central African Gazette; The Central African } \\
\text { Planter; various monographs }\end{array}$ \\
\hline $\begin{array}{l}\text { Msunduzi Municipal Library, } \\
\text { Pietermaritzburg, South Africa }\end{array}$ & Natal Witness newspaper \\
\hline Kew Gardens Archives, London, UK & Various manuscripts \\
\hline Edingul Library of Scotland, & $\begin{array}{l}\text { Manuscript collection (including letters from } \\
\text { Livingstonia Mission, private letters to Robert } \\
\text { Laws, various mission and private journals) }\end{array}$ \\
\hline University of Aberdeen, UK & $\begin{array}{l}\text { Manuscript collection (including Robert Laws of } \\
\text { Livingstonia and Amelia Laws papers) }\end{array}$ \\
\hline University of Glasgow, UK & African Lakes Co Ltd collection \\
\hline University of Edinburgh, UK & $\begin{array}{l}\text { Manuscript collection (including papers of the } \\
\text { missionaries Joseph Booth, Robert Laws, } \\
\text { Alexander Gillon MacAlpine, David Clement) }\end{array}$ \\
\hline $\begin{array}{l}\text { Bodlean Library, University of Oxford, } \\
\text { UK }\end{array}$ & Universities' Mission to Central Africa collection \\
\hline
\end{tabular}

